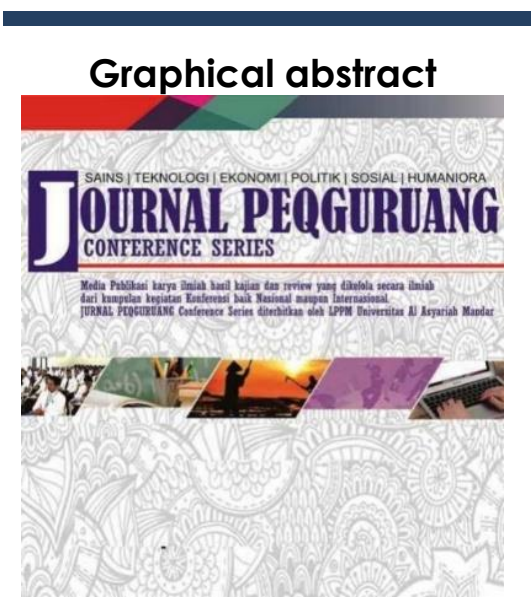

\title{
SPK PEMILIHAN DOSEN TERBAIK MENGGUNAKAN METODE SAW BERBASIS WEB PADA UNIVERSITAS AL ASYARIAH MANDAR.
}

\author{
${ }^{1 *}$ Muhammad Nurhidayat, ${ }^{1}$ Muhammad Assiddiq, ${ }^{1}$ Akhmad \\ Qashlim \\ ${ }^{1}$ Universitas Al Asyariah Mandar \\ *Corresponding author \\ Dayatali46@gmail.com
}

\begin{abstract}
Abstrack
The evaluation and assessment process that will be raised in this study will be proven by concluding the results of questionnaire answers from students, fellow lecturers and the leadership which is the standardization of lecturers' assessment based on lecturer workload (BKD). The evaluation and assessment process is also based on the Tri Dharma of higher education carried out by each lecturer for 1 academic year. The purpose of this study is to design a decision support system for the selection of the best lecturers at the al Asyariah Mandar University based on the assessment criteria carried out in the scope of the university, so that it can be used as a recommendation for the leadership in making decisions to determine the title of best lecturer each year. The type of research used is software engineering research using the PHP programming language. Data collection techniques used in this study are data collection techniques questionnaires, observations, literature studies, and interviews. The data analysis technique used in this study is quantitative research techniques. By using a Webbased Best Lecturer Selection Decision Support System, the best lecturer ranking results will be obtained. The results of the ranking will be used as recommendations for the leadership in making decisions with the title of best lecturer each year. The writing of this thesis was conducted in February to April 2020 with the research location at $\mathrm{Al}$ Asyariah Mandar University.
\end{abstract}

Keywords: System, SPK, Lecturer, SAW

\begin{abstract}
Abstrak
Proses evaluasi dan penilaian yang coba diangkat dalam penelitian ini nantinya akan dibuktikan dengan cara menyimpulkan hasil jawaban kuesioner dari mahasiswa, dosen sejawat dan pihak pimpinan yang merupakan standarisasi penilaian dosen berdasarkan beban kerja dosen (BKD). Proses evaluasi dan penilaian juga berdasarkan Tri Dharma perguruan tinggi yang di lakukan oleh setiap dosen selama 1 tahun akademik. Tujuan penelitian ini adalah membuat rancangan sistem pendukung keputusan pemilihan dosen terbaik pada universitas al asyariah mandar berdasarkan kriteria penilaian yang dilakukan dilingkup universitas, agar dapat menjadi bahan rekomendasi kepada pihak pimpinan dalam pengambilan keputusan untuk menentukan penyandang predikat dosen terbaik setiap tahunnya. Tipe penelitian yang digunakan adalah penelititan rekayaasa perangkat lunak dengan menggunakan bahasa pemprograman PHP. Teknik pengumpulan data yang digunakan dalam penelitian ini adalah Teknik pengumpulan data kuesioner, observasi, studi pustaka, dan wawancara. Teknik analisis data yang digunakan dalam penelitian ini adalah teknik penelitian kuantitatif. Dengan menggunakan Sistem Pendukung Keputusan Pemilihan Dosen Terbaik berbasis Web, maka akan didapatkan informasi hasil perengkingan dosen terbaik. Hasil perengkingan nantinya dapat menjadi bahan rekomendasi bagi pihak pimpinan dalam pengambilan keputusan penyandang predikat dosen terbaik setiap tahunnya.penulisan skripsi ini dilakukan pada bulan Februari sampai dengan bulan April 2020 dengan lokasi penelitian pada Universitas Al Asyariah Mandar.
\end{abstract}

Kata Kunci: Sistem, $S P K$, Dosen, $S A W$

\author{
Article history \\ DOI: http://dx.doi.org/10.35329/ip.v2i1.1479 \\ Received: 03 April 2020 | Received in revised form: 14 April 2020 | Accepted: 28 April 2020
}




\section{PENDAHULUAN}

Universitas Al Asyariah Mandar setiap tahunnya melakukan peningkatan kualitas tenaga pendidik (dosen) dengan memberikan studi lanjutan bagi setiap dosen, hal ini sesuai dengan Undang-undang No 14 tahun 2005 tentang Guru dan Dosen, pasal 51 Ayat (1) Butir b (Sundari et al., 2017), bahwa dosen berhak mendapatkan promosi dan penghargaan sesuai dengan kinerja akademiknya. Namun penilaian yang dilakukan terhadap dosen yang menerima penghargaan berupa studi lanjutan masih menggunakan cara manual melalui kedekatan emosional terhadap pihak-pihak tertentu dan belum menggunakan standarisasi penilaian berdasarkan penilaian beban kerja dosen (BKD) dalam pelakanaan Tri Dharma perguruan tinggi yang lengkap, sehingga masih dirasa kurang efektif dalam proses pemberian apresiasi tersebut.

Proses evaluasi dan penilaian yang coba diangkat dalam penelitian ini nantinya akan dibuktikan dengan cara menyimpulkan hasil jawaban kuesioner dari mahasiswa, dosen sejawat dan pihak pimpinan yang merupakan standarisasi penilaian dosen berdasarkan beban kerja dosen (BKD). Proses evaluasi dan penilaian juga berdasarkan Tri Dharma perguruan tinggi yang di lakukan oleh setiap dosen selama 1 tahun akademik.

Untuk menyimpulkan segala proses diatas maka penulis mencoba merancang suatu "Sistem pendukung Keputusan Pemilihan Dosen Terbaik Menggunakan Metode Simple Additive Weighting (SAW)". Sitem ini diharapkan akan dapat menyelesaikan permasalahan yang dihadapi, dan dapat menghasilkan rekomendasi keputusan yang bisa membantu pihak pimpinan dan tim penilai untuk menetukan siapa yang benar - benar layak mendapat predikat dosen terbaik setiap tahunnya.

Penelitian ini memiliki batasan masalah yaitu aplikasi yang akan digunakan akan digunakan oleh admin aplikasi, LPPM, pihak Prodi, Mahasiswa, Dosen Sejawat, dan Pihak Pimpinan Universitas Al Asyariah mandar. hanya melakukan penilaian untuk satu tahun akademik. Aplikasi menggunakan bahasa pemprograman $\mathrm{PHP}$, sedangkan penyimpanan datanya menggunakan MYSQL.

Tujuan dilakukannya penelitian ini untuk merancang sebuah Sitem Penunjang Keputusan Pemilihan Dosen Terbaik menggunakan Metode Simple Additive Weighting (SAW) berbasis WEB pada Universitas Al Asyariah Mandar yang nantinya dapat digunakan secara rutin setiap tahunnya agar dapat memantau kinerja tenaga pendidik (Dosen) dan lebih memacu semangat tenaga pendidik (Dosen) untuk meningkatkan kualitasnya menjadi lebih baik lagi disetiap tahunnya. Serta menjadi rekomendasi kepada pihak pimpinan untuk menentukan penyandang predikat dosen terbaik yang nantinya akan mendapatkan apresiasi dan penghargaan dari pihak pimpinan Universitas Al Asyariah Mandar.

Penelitian terkait mengenai SPK Pemilihan dosen terbaik seperti halnya yang dilakukan oleh (Marpaung et al., 2018). Yang dimana melakukan penelitian tentang pemilihan dosen terbaik menggunakan metode Weight Product (WP) pada Stimik Royal, (Sundari et al., 2017). Studi kasus AMIK \& STIKOM Tunas bangsa, Penelitian yang dibangun ialah sistem pendukung keputusan dalam merekomendasikan dosen berprestasi bidang ilmu komputer dengan menggunakan analisis pengambilan keputusan multikriteria yaitu Elektre, (Sofhian et al., 2016). Sistem pendukung keputusan pemilihan dosen terbaik menggunakan metode Promethee dan juga menggunakan metode Likert's Summated Rating (LSR) studi kasus pada Universitas Tanjungpura jurusan Teknik Informatika, (Mufizar, 2016). Melakukan penelitian tentang sistem pendukung keputusan pemilihan dosen berprestasi di Stimik Tasikmalaya menggunakan metode Simple Additive Weighting (SAW),(Rini et al., 2015). Melakukan penelitian tentang sistem pendukung keputusan pemilihan dosen terbaik menggunakan metode Simple Additive Weighting (SAW) studi kasus pada STIMIK Global Tangerang, (Qashlim, 2015) Melakukan Penelitian Tentang Penerapan Metode Analytic Hierarchy Process (AHP) Untuk Sistem Pedukung Keputusan (Sudi Kasus: Penentuan Kawasan Hutan Konservasi), dan Penelitian terkait terakhir adalah penelitian yang dilakukan oleh (Amiruddin et al., 2018) yang melakukan penelitian tentang Rancangan Aplikasi Sistem Pendukung Keputusan (SPK) Pengangkatan Karyawan Menggunakan Metode Simple Additive Weighting (SAW) Pada PT. Ultra Prima Plast Flexible Packaging.

Dari berbagai penelitian terkait diatas penulis dapat mengambil kesimpulan bahwa dalam menentukan dosen terbaik dapat menggunakan berbagai metode penelitian dan berbagai kriteria penilaian, namun mengenai pengaplikasiannya harus disesuaikan dengan kondisi lingkup tempat penelitian dan dalam penentuan kriteria penilaian yang digunakan harus jelas dan tepat sasaran.

\section{METODE PENELITIAN}

Penelitian dilakukan dengan cara mengumpulkan seluruh bahan penelitian pada Universitas Al Asyariah Mandar yang akan digunakan pada proses pemilihan dosen terbaik. Seluruh bahan kemudian dihimpun dan dipadukan dengan kriteria penilaian yang digunakan pada aplikasi.

Bahan yang digunakan dalam penelitian ini adalah data dari 5 orang Dosen yang berada di Fakultas Ilmu Komputer Program Studi Teknik Informatika Universitas Al Asyariah Mandar sebagai sample awal. Data tersebut meliputi: 
Biodata Dosen

Tabel 1: Biodata Dosen

\begin{tabular}{|c|c|c|c|c|c|}
\hline No & NIDN & Nama Dosen & Alamat & $\begin{array}{l}\text { Pendi } \\
\text { dikan }\end{array}$ & Jabatan \\
\hline 1 & $\begin{array}{l}09050 \\
78702\end{array}$ & $\begin{array}{l}\text { Basri, } \\
\text { S.Kom., MT }\end{array}$ & Polewali & $\mathrm{S} 2$ & $\begin{array}{l}\text { Asisten } \\
\text { Ahli }\end{array}$ \\
\hline 2 & $\begin{array}{l}09180 \\
78601\end{array}$ & $\begin{array}{l}\text { Akhmad } \\
\text { Qashlim, } \\
\text { S.Kom., } \\
\text { M.Kom }\end{array}$ & Polewali & $\mathrm{S} 2$ & Lektor \\
\hline 3 & $\begin{array}{l}09301 \\
28408\end{array}$ & $\begin{array}{l}\text { Syarli Jalal, } \\
\text { S.Kom., } \\
\text { M.Kom }\end{array}$ & Mapilli & S2 & $\begin{array}{l}\text { Asisten } \\
\text { Ahli }\end{array}$ \\
\hline 4 & $\begin{array}{l}09080 \\
87901\end{array}$ & $\begin{array}{l}\text { Rosmawati } \\
\text { Tamin,S.Kom } \\
\text {.,M.Kom }\end{array}$ & $\begin{array}{l}\text { Takatid } \\
\text { ung }\end{array}$ & S2 & $\begin{array}{l}\text { Asisten } \\
\text { Ahli }\end{array}$ \\
\hline 5 & $\begin{array}{l}09210 \\
98504\end{array}$ & $\begin{array}{l}\text { Herlina } \\
\text { Ahmad,S.Pd., } \\
\text { M.Pd }\end{array}$ & Polewali & S2 & Pengajar \\
\hline
\end{tabular}

1. Hasil Penilaian Mahasiswa (C1)

Hasil penilaian mahasiswa diperoleh melalui hasil jawaban kuesioner yang telah diselesaikan oleh sekurang kurangnya 20\% mahasiswa dari setiap angkatan pada Fakultas Ilmu Komputer Prodi Teknik Informatika Universitas Al Asyariah Mandar. Total mahasiswa yang melakukan penilaian sebanyak 30 orang mahasiswa (i).

2. Hasil Penilaian Dosen Sejawat (C2)

Hasil penilaian dosen sejawat diperoleh melalui hasil jawaban kuesioner yang telah diselesaikan oleh sekurang kurangnya $20 \%$ dosen sejawat yang berada pada Fakultas Ilmu Komputer Universitas Al Asyariah Mandar. Total dosen sejawat yang melakukan penilaian sebanyak 5 orang dosen sejawat.

3. Hasil Penilaian Pimpinan (C3)

Hasil penilaian pimpinan diperoleh melalui hasil jawaban kuesioner yang telah diselesaikan oleh 1 orang pihak pimpinan Universitas Al Asyariah Mandar.

4. Kualifikasi Pendidikan (C4)

Data tentang kualifikasi pendidikan dosen peserta diperoleh melalui pihak Staff Fakultas Ilmu Komputer Universitas Al Asyariah Mandar.

5. Jumlah Penelitian Dosen (C5)

Data jumlah penelitian yang telah dilakukan dosen peserta selama kurun waktu 1 tahun terakhir diperoleh melalui pihak LPPM Universitas $\mathrm{Al}$ Asyariah Mandar.

6. Jumlah Jurnal terbitan Dosen (C6)

Data jumlah jurnal yang telah diterbitkan oleh dosen peserta selama kurun waktu 1 tahun terkahir diperoleh melalui pihak LPPM Universitas Al Asyariah Mandar.

7. Jumlah Pelatihan/kursus yang diikuti oleh Dosen (C7)

Data jumlah pelatihan/kursus yang telah dilakukan oleh dosen peserta selama kurun waktu 1 tahun terakhir diperoleh melalui wawancara terhadap dosen yang berangkutan dan wawancara kepada pihak LPPM Universitas Al Asyariah Mandar.
8. Jumlah Seminar yang telah diikuti oleh Dosen (C8) Data jumlah seminar yang telah dilakukan dosen peserta selama kurun waktu 1 tahun terakhir diperoleh melalui pihak LPPM Universitas $\mathrm{Al}$ Asyariah Mandar.

9. Jumlah Pengabdian Mayarakat (C9)

Data jumlah pengabdian masyarakat yang telah dilakukan oleh dosen peserta selama kurun waktu 1 tahun terakhir diperoleh melalui pihak LPPM Universitas Al Asyariah Mandar.

10. Jabatan Akademik/fungsional Dosen (C10)

Data tentang kualifikasi pendidikan dosen peserta diperoleh melalui pihak Staff Fakultas Ilmu Komputer Universitas Al Asyariah Mandar.

Seluruh proses perancangan aplikasi akan ditunjukkan pada kerangka sistem yang terdapat pada gambar 1 dan hasil analisis data dan desain sistem akan ditunjukkan pada gambar 2 sebagai berikut:

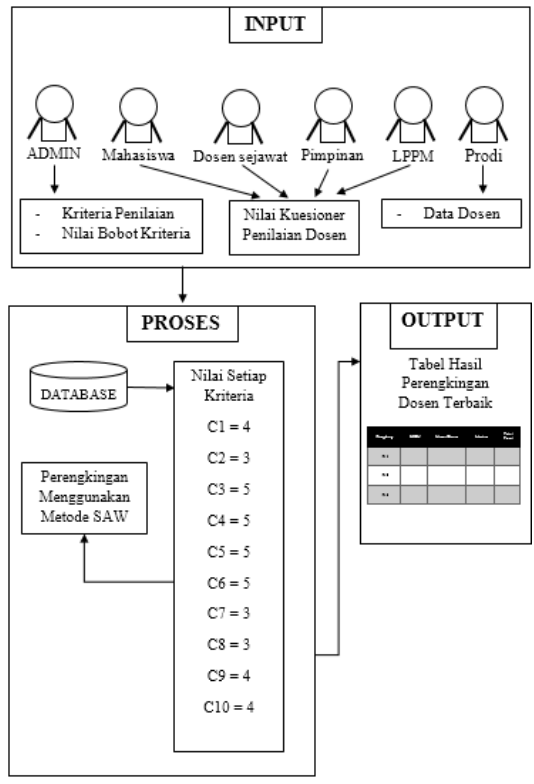

Gambar 1: Kerangka Sistem 


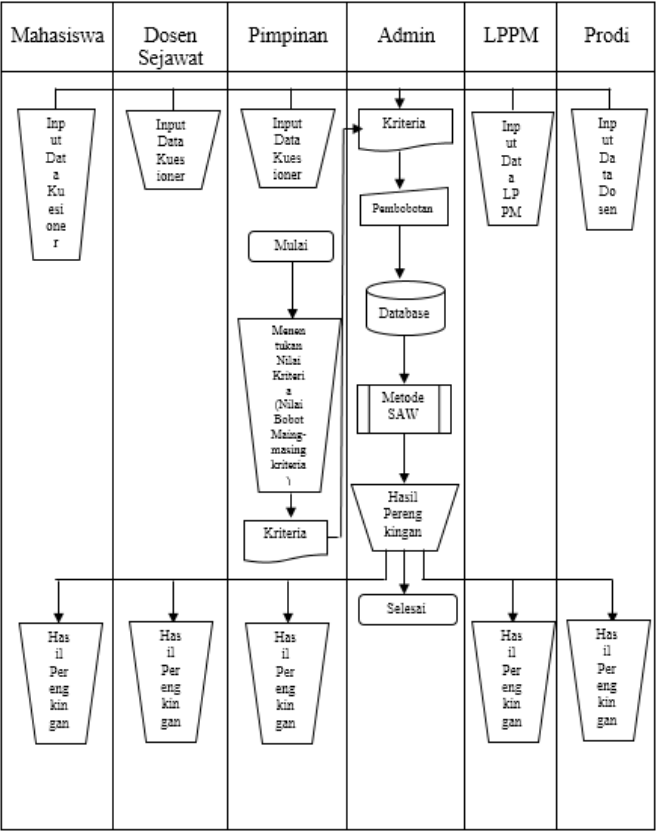

Gambar 2: Analisis dan desain sistem

\section{Implementasi Metode Simple Additive Weighting (SAW)}

Konsep dasar metode SAW adalah mencari penjumlahan terbobot dari rating kinerja pda setiap alternative dari emua atribut. Metode SAW membututuhkan proses normalisasi matriks keputusan (X) ke suatu skala yang dapat diperbandingkan dengan semua rating alternatif yang ada. Metode SAW mengharuskan pembuat keputusan menentukan bobot bagi setiap atribut. Skor total untuk alternative diperoleh dengan menjumlahkan seluruh hasil perkalian antar rating (yang dapat dibandingkan lintas atribut) dan bobot tiap atribut. Rating tiap atribut haruslah bebas dimensi dalam arti telah melewati proses normalisasi matriks sebelumnya.

Diberikan persamaan (1):

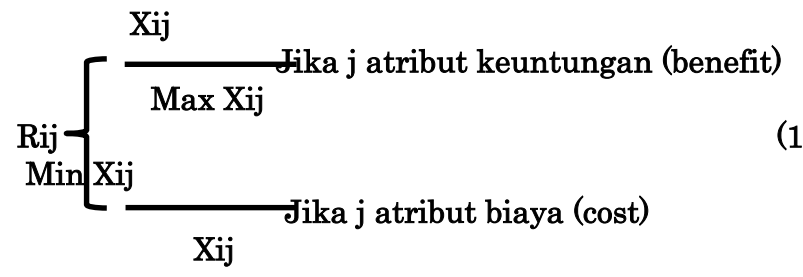

Dimana: rij adalah rating kinerja ternormalisasi dari alternatif $\mathrm{Ai}$ pada atribut $\mathrm{Cj}$; $\mathrm{i}=1,2, \ldots, \mathrm{m}$ dan $\mathrm{j}=1,2, \ldots, \mathrm{n}$. Nilai preferensi untuk setiap alternatif $(\mathrm{Vi})$ diberikan persamaan (2):

$$
\begin{aligned}
& \mathrm{n} \\
& \mathrm{Vi}=\sum \text { wj rij } \\
& \mathrm{j}=1 \\
& \text { Keterangan: } \\
& \mathrm{Vi} \quad=\text { nilai prefensi } \\
& \mathrm{wj} \quad=\text { bobot rangking } \\
& \mathrm{rij} \quad=\text { rating kinerja ternormalisasi }
\end{aligned}
$$

Nilai Vi yang lebih besar mengindikasikan bahwa alternatif Ai lebih terpilih.

\section{HASIL DAN PEMBAHASAN}

\section{Hasil Perancangan \\ Rancangan Data Flow Diagram}

Rancangan Data Flow Diagram (DFD) digunakan untuk menggambarkan secara keseluruhan mengenai sistem yang telah dikembangkan secara logis. rancangan DFD tersebut dapat dilihat pada gambar 3,4 dan 5 sebagai berikut:

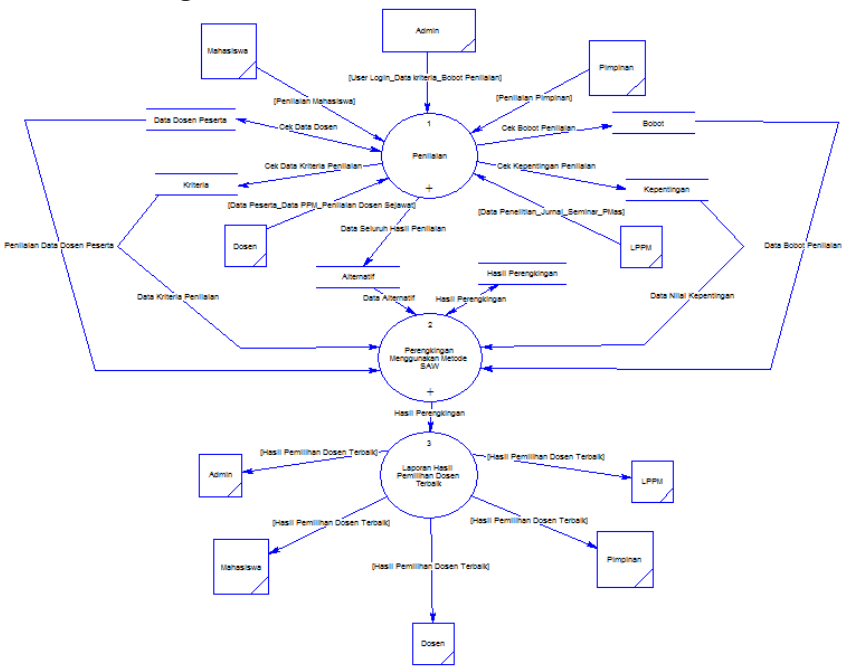

Gambar 3: Rancangan DFD Level 0

Gambar diatas merupakan proses kerja yang dilakukan oleh sistem yaitu proses penilaian, proses perengkingan menggunakan metode SAW, dan proses memberikan laporan hasil pemilihan yang dilakukan oleh sistem berupa data hasil pemilihan dosen terbaik.

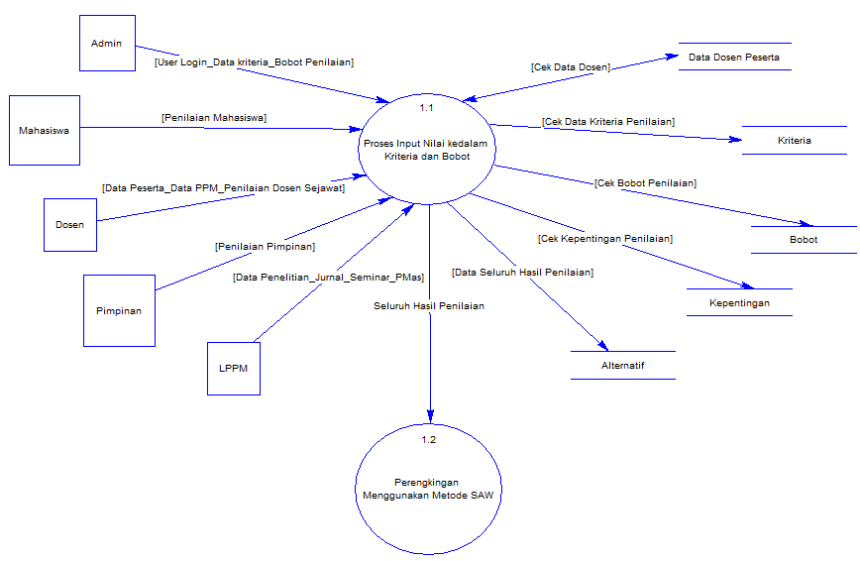

Gambar 4: Rancangan DFD Level 1

Gambar diatas merupakan gambaran proses penilaian yang dilakukan oleh sistem yaitu:

1. Admin menginput user login untuk mahasiswa, dosen, pimpinan dan lppm kedalam sistem.

2. Mahasiswa menginput data hasil quesioner penilaian kedalam sistem.

3. Dosen menginput data dosen untuk mendaftar sebagai peserta pemilihan dosen terbaik, memasukkan data jumlah penelitian, jumlah jurnal, 
jumlah pelatihan/kursus, jumlah seminar yang diikuti, dan jumlah pengabdian masyarakat yang dilakukan, yang nantinya seluruh data akan di verifikasi oleh pihak Lppm.

Dosen juga menginput data hasil quesioner penilaian kedalam sistem.

Dosen yang menginput data dosen untuk mendaftar dalam pemilihan dosen terbaik tidak dapat melakukan penilaian quesioner. Dosen yang melakukan penilaian quesioner adalah dosen yang tidak terdaftar sebagai peserta pemilihan dosen terbaik.

4. Pimpinan menginput data hasil quesioner penilaian kedalam sistem

5. LPPM menginput data jumlah penelitian, jumlah jurnal, jumlah pelatihan/kursus, jumlah seminar yang diikuti dan jumlah pengabdian masyarakat yang dilakukan oleh dosen peserta. Data yang diinput pihak lppm nantinya kan dicocokkan dengan data yang diinput oleh dosen peserta sehingga data bisa dijanyatakan valid.

Seluruh hasil inputan nantinya akan di cek dan dicocokkan dengan database kemudian diteruskan ke proses perhitungan dan penilaian menggunakan metode saw (simple additive weighting).

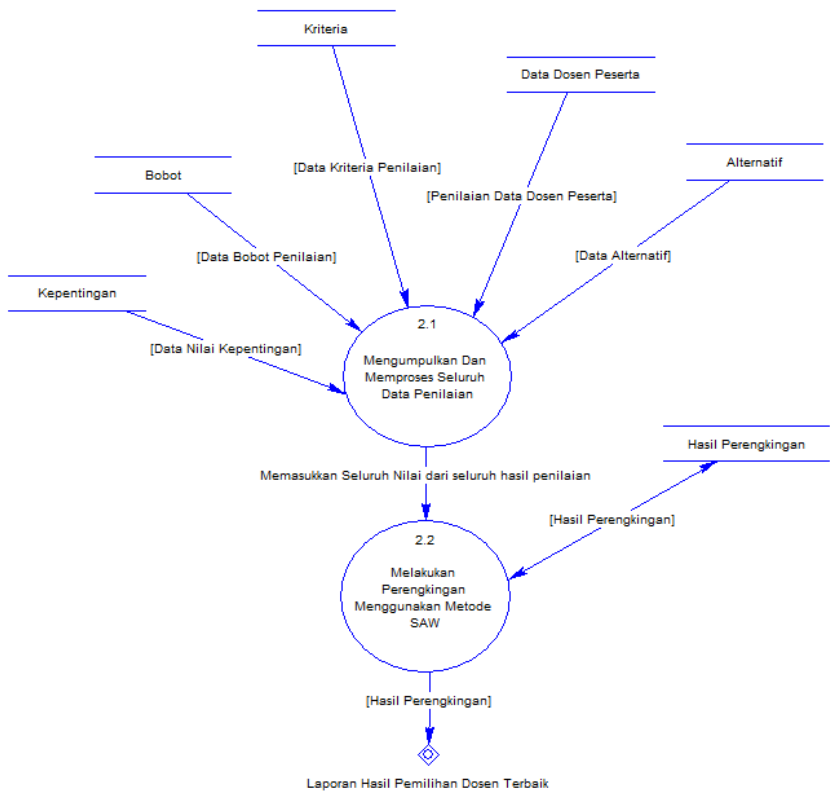

Gambar 5: Rancangan DFD Level 2

Gambar diatas menjelaskan proses perengkingan yang dilakukan oleh sistem yaitu seluruh data di cek berdasarkan kriterianya, jumlah bobot, dan tingkat kepentingan, kemudian dihitung menggunakan rumus benefit metode saw karena sistem dirancang untuk mencari nilai tertinggi.

Nilai tertinggi dan seluruh data hasil perhitungan akan diteruskan ketahapan selanjutnya yaitu memberikan laporan hasil perhitungan pemilihan dosen terbaik.

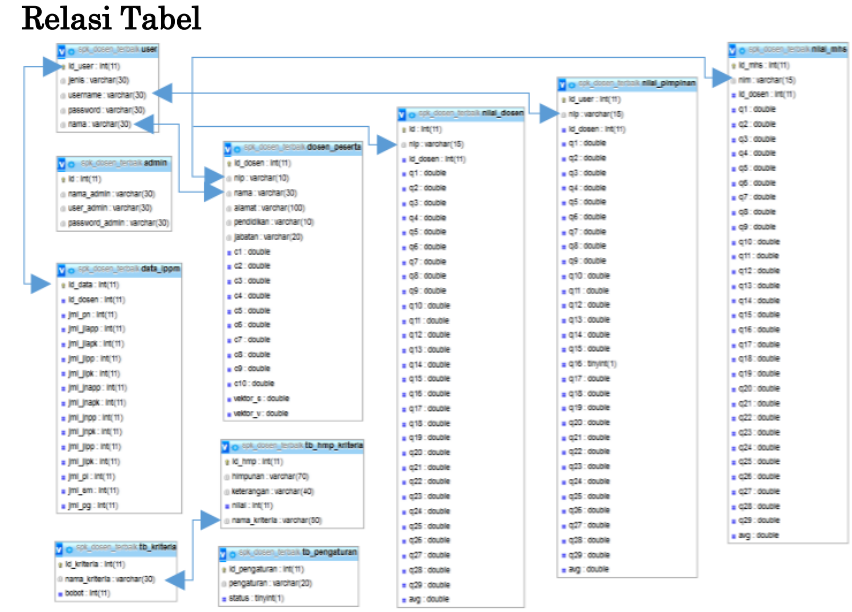

Gambar 6: Relasi Tabel

Relasi tabel menunjukkan seluruh data relasi tabel dan penyimpanan yang terdapat pada sistem pendukung keputusan pemilihan dosen terbaik diantaranya:

1. Pada tabel user terjadi relasi dengan tebel dosen peserta, tabel nilai dosen, tabel nilai pimpinan, tabel nilai mhs dan tabel data lppm.

2. Pada tabel kriteria terjadi relasi dengan tabel himp kriteria.

\section{Hasil Pengembangan Sistem}

\section{Tampilan Menu Utama (Interface Pengguna)}

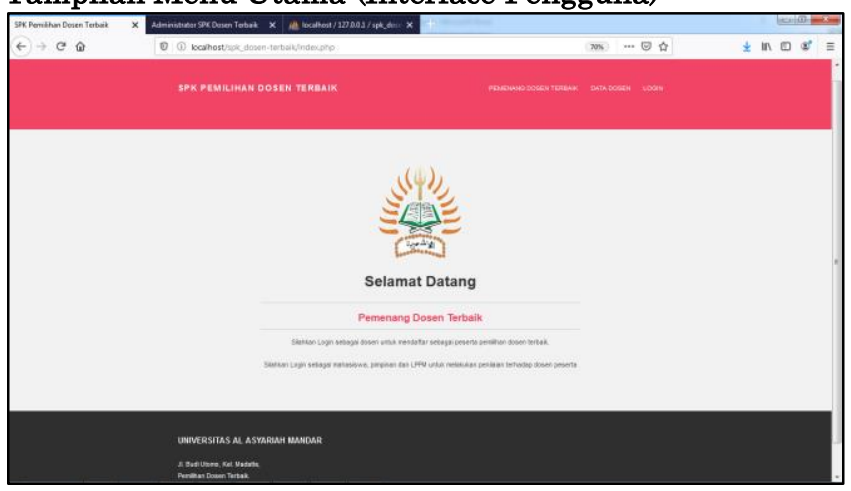

Gambar 7: Tampilan Menu Utama

Halaman interface pengguna merupakan halawan awal yang ditemui oleh pengguna aplikasi ketika ingin menginput penilaian dosen terbaik. Halaman ini berisi menu pemenang dosen terbaik, menu data dosen, dan menu login. 


\section{Tampilan Menu Pemenang (Hasil Penelitian)}

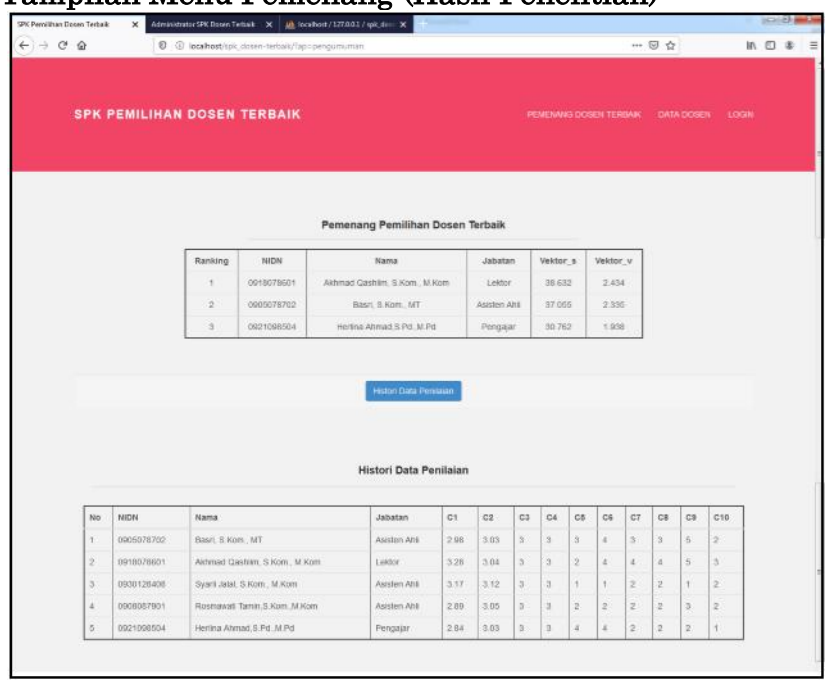

Gambar 8: Tampilan Menu Pemenang Dosen Terbaik

Hasil pemenang pemilihan dosen terbaik merupakan seluruh hasil perhitungan dari penilaian quesioner mahasiswa (C1), penilaian quesioner dosen sejawat (C2), penilaian quesioner pimpinan (C3), penilaian kualifikasi pendidikan (C4), penilaian jumlah penelitian yang dilakukan selama 1 tahun terakhir (C5), penilaian jumlah jurnal yang diterbitkan selama 1 tahun terakhir (C6), penilaian jumlah pelatihan / kursus yang diikuti selama 1 tahun terakhir (C7), penilaian jumlah seminar yang diikuti pada 1 tahun terakhir (C8), penilaian jumlah pengabdian masyarakat yang dilakukan selama 1 tahun terakhir (C9), dan penilaian jabatan akademik yang diperoleh dosen pada tahun terakhir.

\section{Tampilan Menu Data Dosen}

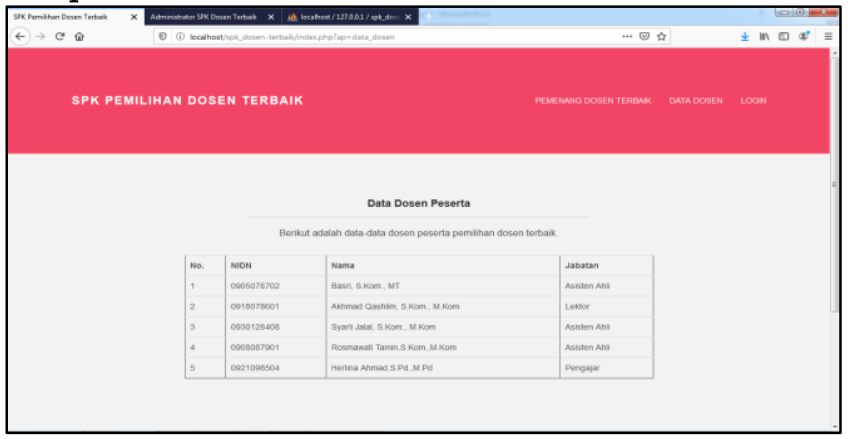

Gambar 9: Tampilan Data Dosen

Halaman interface data dosen berisi tabel pemberitahuan data jumlah dosen yang menjadi peserta pemilihan dosen terbaik.
Tampilan Login Mahasiswa (Penilaian Quesioner)

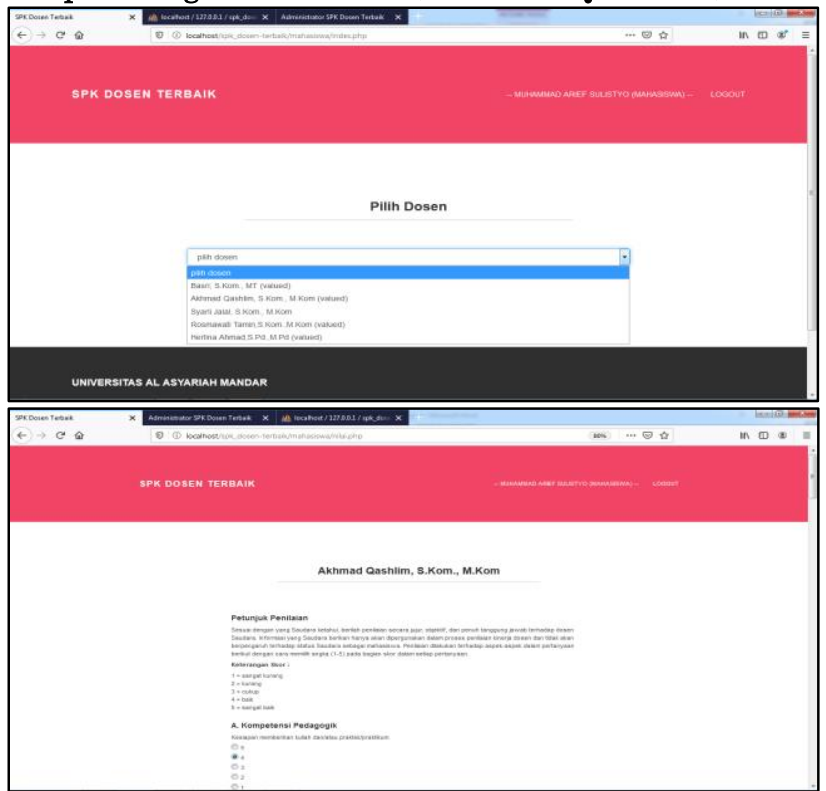

Gambar 10: Tampilan Login Mahasiswa

Tampilan interface penilaian mahasiswa berisi tampilan untuk melakukan pengisian quesioner dengan tahapan awal yaitu memilih dosen yang akan dinilai kemudian menjawab seluruh pertanyaan quesioner menggunakan skor peniliaian 1-5 yang merupakan kriteria penilaian $\mathrm{C} 1$.

Tampilan Login Dosen (Penilaian Quesioner)

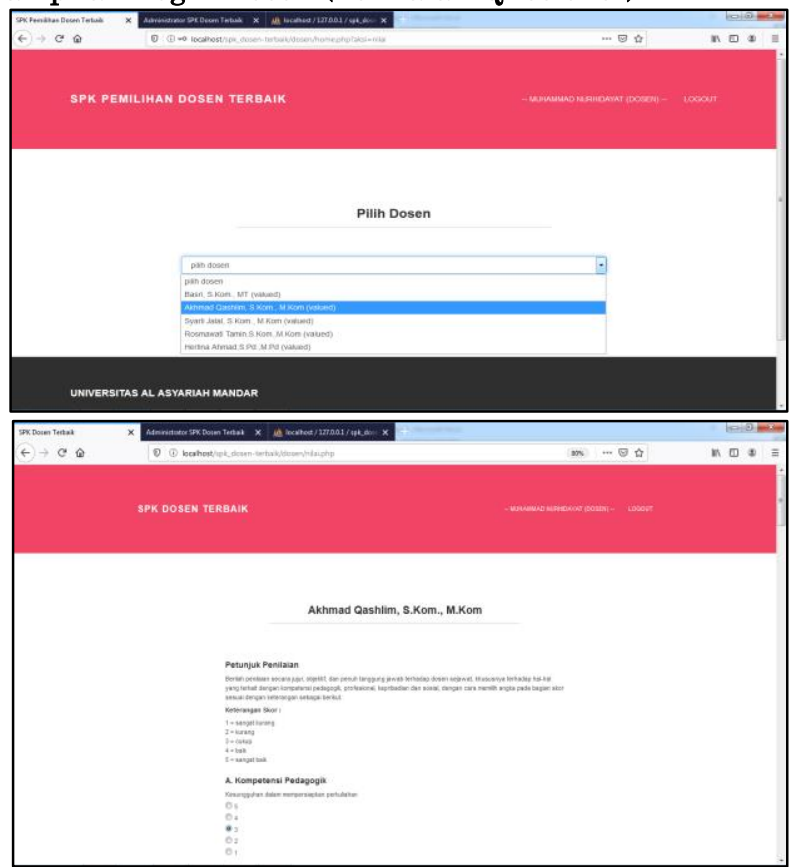

Gambar 11: Tampilan Login Dosen

Tampilan interface penilaian Dosen Sejawat berisi tampilan untuk melakukan pengisian quesioner dengan tahapan awal yaitu memilih dosen yang akan dinilai kemudian menjawab seluruh pertanyaan quesioner menggunakan skor peniliaian 1-5 yang merupakan kriteria penilaian $\mathrm{C} 2$. 


\section{Tampilan Daftar Peserta}

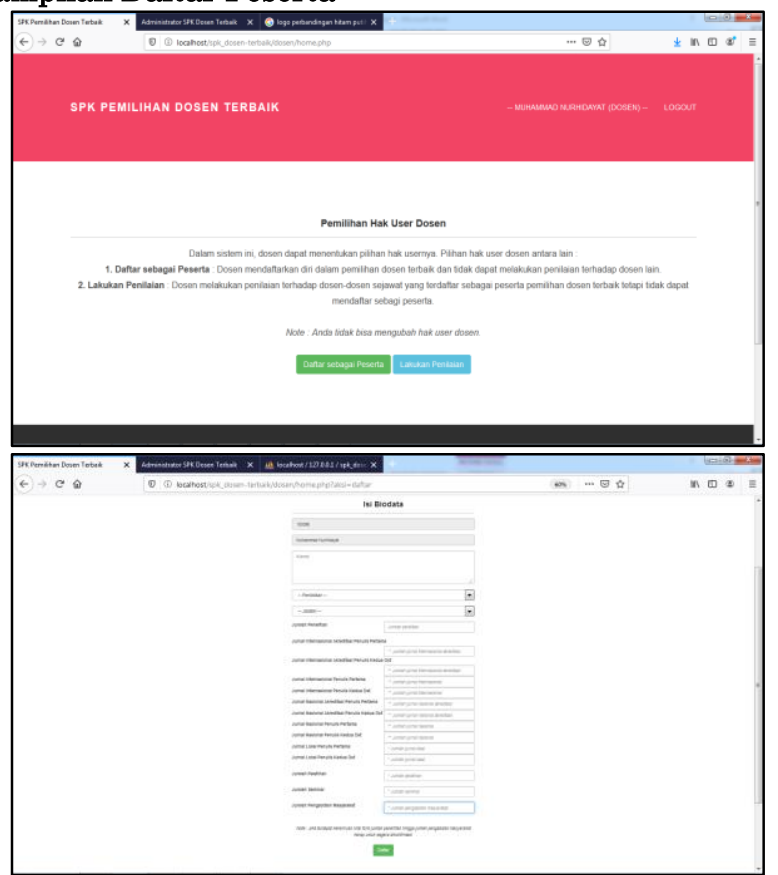

Gambar 12: Tampilan Daftar Peserta

Pada tampilan interface login dosen, dosen akan diminta untuk memilih ingin mendaftar sebagai peserta (tidak dapat melakukan penilaian) atau melakukan penilaian (tidak dapat mendaftar sebagai peserta).

Jika memilih mendaftar sebagai peserta maka dosen akan diminta untuk mengisi data sesuai dengan format pendaftaran peserta yang ditampilkan oleh aplikasi. Format pendaftaran yang diisi oleh dosen peserta akan di cek dan divalidasi oleh pihak LPPM, karena pada format pendaftaran peserta terdapat kriteria penilaian $\mathrm{C} 4$ - C10.

\section{Tapilan Login Pimpinan (Penilaian Quesioner)}

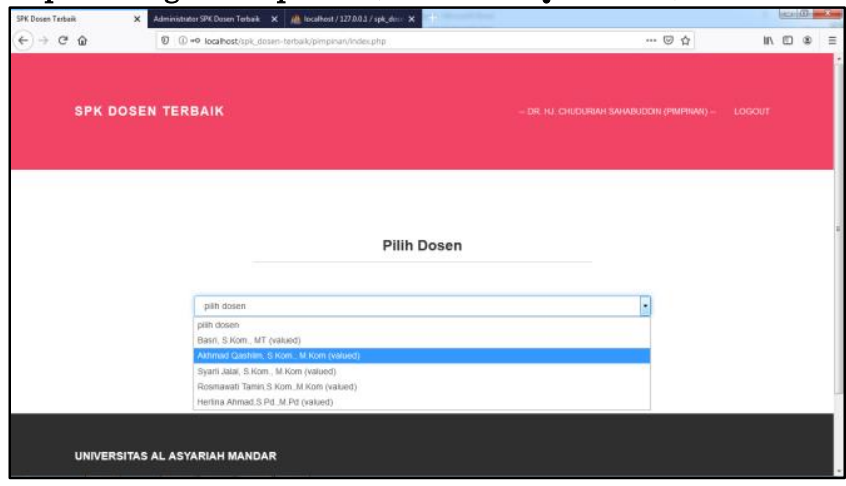

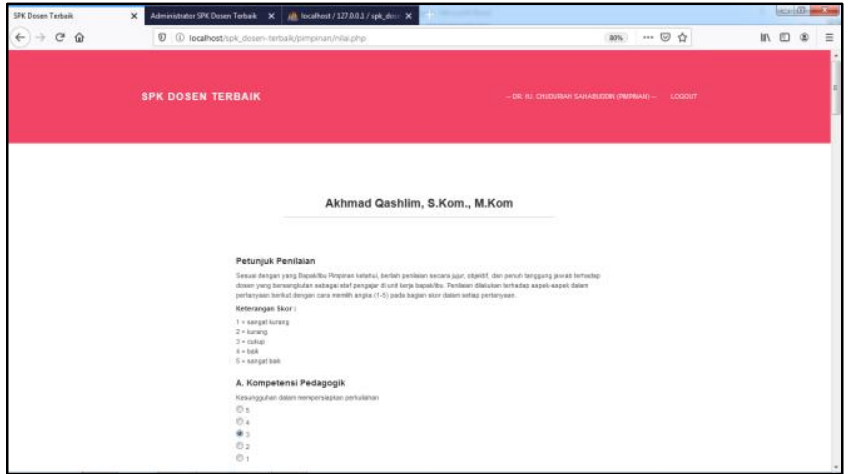

Gambar 13: Tampilan Login Pimpinan

Tampilan interface penilaian Pimpinan berisi tampilan untuk melakukan pengisian quesioner dengan tahapan awal yaitu memilih dosen yang akan dinilai kemudian menjawab seluruh pertanyaan quesioner menggunakan skor peniliaian 1-5 yang merupakan kriteria penilaian C3.

Tampilan Login LPPM (Penilaian Quesioner)

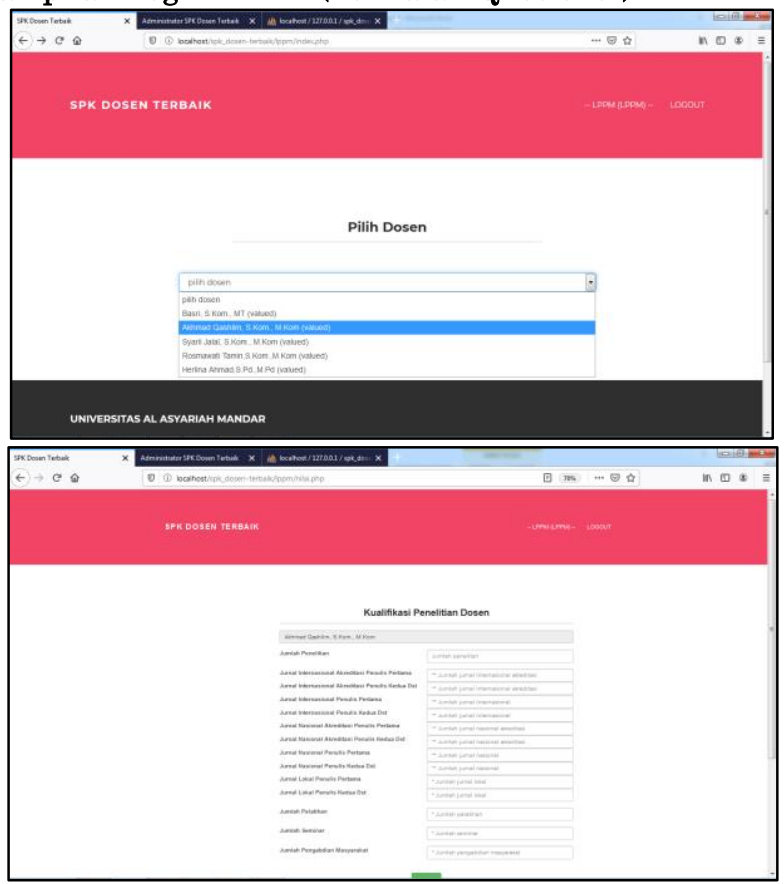

Gambar 14: Tampilan Login LPPM

Tampilan interface penilaian lppm berisi tampilan form pengisian kriteria penilaian C5 - C10 yang diperoleh oleh dosen peserta selama 1 tahun terakhir. form inputan yang akan di isi oleh pihak lppm akan di cocokkan dengan data yang diinput oleh dosen peserta. 
Uji Coba Sistem Dan Program Implementasi Pengujian Whitebox Tabel 2: Pengujian Whitebox

\begin{tabular}{ccccc}
\hline No & Flowgraph & $\begin{array}{c}\text { Cyclomatic } \\
\text { complexcity }\end{array}$ & $\begin{array}{c}\text { Predica } \\
\text { te Node }\end{array}$ & Path \\
\hline $\mathbf{1}$ & Menu Utama & 2 & 2 & 2 \\
\hline $\mathbf{2}$ & $\begin{array}{c}\text { Menu } \\
\text { Pemenang }\end{array}$ & 2 & 2 & 2 \\
\hline $\mathbf{3}$ & $\begin{array}{c}\text { Menu Data } \\
\text { Dosen }\end{array}$ & 2 & 2 & 2 \\
\hline $\mathbf{4}$ & $\begin{array}{c}\text { Login } \\
\text { Mahasiswa }\end{array}$ & 4 & 6 & 6 \\
\hline $\mathbf{5}$ & Login Dosen & 4 & 6 & 6 \\
\hline $\mathbf{6}$ & $\begin{array}{c}\text { Daftar } \\
\text { peserta }\end{array}$ & 4 & 6 & 6 \\
\hline $\mathbf{7}$ & $\begin{array}{c}\text { Login } \\
\quad \text { Pimpinan }\end{array}$ & 4 & 6 & 6 \\
\hline $\mathbf{8}$ & Login LPPM & 4 & 6 & 6 \\
\hline $\mathbf{9}$ & Total & $\mathbf{2 6}$ & $\mathbf{3 6}$ & $\mathbf{3 6}$ \\
\hline
\end{tabular}

Berdasarkan tabel hasil pengujian whitebox diatas maka disimpulkan bahwa program aplikasi yang dirancang dianggap valid. Dalam hal ini program dinyatakan telah bebas dari error dan kesalahan logika dengan beberapa asumsi sebagai berikut:

a. Dapat menjamin seluruh Independet Path di dalam modul yang dikerjakan sekurang-kurangnya satu kali.

b. Dapat mengerjakan seluruh keputusan logikal dan seluruh loop yang sesuai dengan batasannya, juga dapat mengerjakan seluruh struktur dasar internal yang menjamin validitas.

Implementasi Pengujian Blackbox

Tabel 3: Pengujian Blackbox Menu Utama Pengguna

\begin{tabular}{|c|c|c|c|}
\hline No. & $\begin{array}{l}\text { Rancangan } \\
\text { Proses }\end{array}$ & $\begin{array}{l}\text { Hasil Yang } \\
\text { diharapkan }\end{array}$ & Hasil \\
\hline 1. & $\begin{array}{l}\text { Klik Halaman } \\
\text { Web }\end{array}$ & $\begin{array}{l}\text { Masuk ke } \\
\text { Halaman Utama }\end{array}$ & Sesuai \\
\hline 2. & $\begin{array}{l}\text { Klik menu } \\
\text { Login }\end{array}$ & $\begin{array}{l}\text { Membuka } \\
\text { Halaman Login }\end{array}$ & Sesuai \\
\hline & $\begin{array}{l}\text { Klik Lakukan } \\
\text { Penilaian } \\
\text { Mahasiswa, } \\
\text { Dosen Sejawat, } \\
\text { Pimpinan Dan } \\
\text { LPPM }\end{array}$ & $\begin{array}{l}\text { Membuka } \\
\text { seluruh Form } \\
\text { Penilaian } \\
\text { Mahasiswa, } \\
\text { Dosen Sejawat, } \\
\text { Pimpinan Dan } \\
\text { LPPM }\end{array}$ & Sesuai \\
\hline 3. & $\begin{array}{l}\text { Klik Menu Data } \\
\text { Dosen }\end{array}$ & $\begin{array}{l}\text { Membuka } \\
\text { Halaman Data } \\
\text { Dosen }\end{array}$ & Sesuai \\
\hline 4. & $\begin{array}{l}\text { Klik Menu } \\
\text { Pemenang } \\
\text { Dosen Terbaik }\end{array}$ & $\begin{array}{l}\text { Membuka } \\
\text { Halaman } \\
\text { Pemenang Dosen } \\
\text { Terbaik }\end{array}$ & Sesuai \\
\hline
\end{tabular}

Tabel 4: Pengujian Blackbox Halaman Login Admin

\begin{tabular}{llll} 
No. & $\begin{array}{l}\text { Rancangan } \\
\text { Proses }\end{array}$ & $\begin{array}{l}\text { Hasil Yang } \\
\text { diharapkan }\end{array}$ & Hasil \\
\hline 1. & $\begin{array}{l}\text { Ketik Menu } \\
\text { Login }\end{array}$ & $\begin{array}{l}\text { Masuk ke } \\
\text { Halaman login }\end{array}$ & Sesuai \\
\hline 2. & $\begin{array}{l}\text { Mengisi Form } \\
\text { Login }\end{array}$ & $\begin{array}{l}\text { Membuka } \\
\text { Halaman utama } \\
\text { menu admin }\end{array}$ & Sesuai \\
\hline
\end{tabular}

Tabel 5: Pengujian Menu Halaman Interface Login

\begin{tabular}{|c|c|c|c|}
\hline No. & $\begin{array}{l}\text { Rancangan } \\
\text { Proses }\end{array}$ & $\begin{array}{l}\text { Hasil Yang } \\
\text { diharapkan }\end{array}$ & Hasil \\
\hline 1. & $\begin{array}{l}\text { Klik Menu } \\
\text { Beranda }\end{array}$ & $\begin{array}{l}\text { Masuk ke } \\
\text { Halaman } \\
\text { Beranda }\end{array}$ & Sesuai \\
\hline 2. & $\begin{array}{l}\text { Klik Menu } \\
\text { Data Peserta }\end{array}$ & $\begin{array}{l}\text { Masuk ke } \\
\text { Halaman Data } \\
\text { Peserta }\end{array}$ & Sesuai \\
\hline & $\begin{array}{l}\text { Klik Add Dosen } \\
\text { Pada Menu } \\
\text { Data Peserta }\end{array}$ & $\begin{array}{l}\text { Masuk ke } \\
\text { Halaman Add } \\
\text { Dosen }\end{array}$ & Sesuai \\
\hline & $\begin{array}{l}\text { Klik Update } \\
\text { Pada Menu } \\
\text { Data Peserta }\end{array}$ & $\begin{array}{l}\text { Masuk ke } \\
\text { Halaman Update } \\
\text { Data Peserta }\end{array}$ & Sesuai \\
\hline & $\begin{array}{l}\text { Klik Delete } \\
\text { Pada Menu } \\
\text { Data Peserta }\end{array}$ & $\begin{array}{l}\text { Menghapus Data } \\
\text { Dosen Peserta } \\
\text { Yang Dipilih }\end{array}$ & Sesuai \\
\hline 3. & $\begin{array}{l}\text { Klik Menu } \\
\text { Data Kriteria }\end{array}$ & $\begin{array}{l}\text { Masuk ke } \\
\text { Halaman Data } \\
\text { Kriteria }\end{array}$ & Sesuai \\
\hline 4. & $\begin{array}{l}\text { Klik Menu } \\
\text { Himpunan } \\
\text { Kriteria }\end{array}$ & $\begin{array}{l}\text { Masuk ke } \\
\text { Halaman } \\
\text { Himpunan } \\
\text { Kriteria }\end{array}$ & Sesuai \\
\hline & $\begin{array}{l}\text { Klik Pilih } \\
\text { Kriteria pada } \\
\text { Menu } \\
\text { Himpunan } \\
\text { Kriteria }\end{array}$ & $\begin{array}{l}\text { Menampilkan } \\
\text { Daftar Kriteria } \\
\text { dan Himpunan } \\
\text { Kriteria }\end{array}$ & Sesuai \\
\hline 5. & $\begin{array}{l}\text { Klik Menu } \\
\text { Perhitungan }\end{array}$ & $\begin{array}{l}\text { Masuk ke } \\
\text { Halaman } \\
\text { Perhitungan }\end{array}$ & Sesuai \\
\hline & $\begin{array}{l}\text { Klik Hitung } \\
\text { pada Manu } \\
\text { Perhitungan }\end{array}$ & $\begin{array}{l}\text { Aplikasi } \\
\text { Menampilkan } \\
\text { Hasil } \\
\text { Perhitungan }\end{array}$ & Sesuai \\
\hline 6. & $\begin{array}{l}\text { Klik Menu } \\
\text { Pengaturan }\end{array}$ & $\begin{array}{l}\text { Masuk ke } \\
\text { Halaman } \\
\text { Pengaturan }\end{array}$ & Sesuai \\
\hline & $\begin{array}{l}\text { Klik Opsi Aktif } \\
\text { dan Tidak Aktif } \\
\text { Pada } \\
\text { Pendaftaran } \\
\text { Peserta }\end{array}$ & $\begin{array}{l}\text { Membuka dan } \\
\text { Menutup } \\
\text { Pendaftaran } \\
\text { Peserta Pada } \\
\text { Aplikasi }\end{array}$ & Sesuai \\
\hline & $\begin{array}{l}\text { Klik Opsi Aktif } \\
\text { dan Tidak Aktif } \\
\text { Pada } \\
\text { Penilaian/kuesi }\end{array}$ & $\begin{array}{l}\text { Membuka dan } \\
\text { Menutup } \\
\text { Penilaian/Kuesio } \\
\text { ner Pengguna }\end{array}$ & Sesuai \\
\hline
\end{tabular}




\begin{tabular}{|c|c|c|c|}
\hline & oner & Pada Aplikasi & \\
\hline & Klik Opsi Aktif & Menampilkan & Sesuai \\
\hline & dan Tidak Aktif & Dan Tidak & \\
\hline & Pada & Menampilkan & \\
\hline & Pengumuman & Menu & \\
\hline & Pemenang & Pengumuman & \\
\hline & & Pemenang Pada & \\
\hline & & Aplikasi. & \\
\hline 7. & Klik Menu Sign & Keluar dari & Sesuai \\
\hline & Out & Halaman admin & \\
\hline
\end{tabular}

Perhitungan Manual Menggunakan Ms. Ofiice Excell

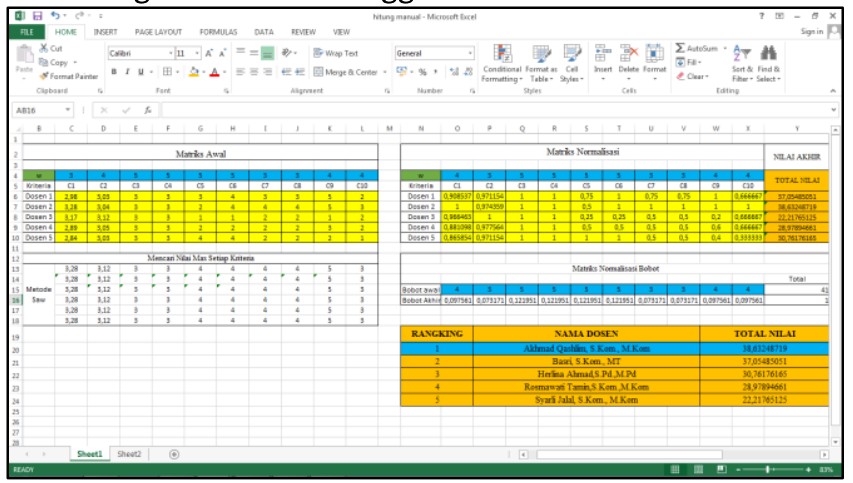

Gambar 15: Pengujian Perhitungan Manual

Gambar diatas menunjukkan metode perhitungan nilai yang dilakukan oleh sistem pendukung keputusan pemilihan dosen terbaik, yang dimana penjelasannya adalah sebagai berikut:

1. Matriks awal merupakan data seluruh penilaian alternatif berdasarkan seluruh kriteria yang telah dihitung kemudian di rata-data (AVERAGE) serta dicocokkan dengan seluruh nilai bobot sub masing masing kriteria.

2. Matriks nilai max setiap kriteria merupakan nilai tertinggi yang diperoleh seluruh alternatif pada setiap kriteria.

3. Matriks Normalisasi merupakan hasil pembagian dari seluruh data Matriks Awal dan Matriks nilai max setiap keriteria.

4. Untuk memperoleh nilai akhir pada tabel matriks normalisasi caranya adalah mengkalikan seluruh nilai kriteria yang diperoleh setiap alternatif dengan jumlah bobot setiap kriteria kemudian menjumlah seluruh hasil pengkalian sehingga menghasilkan nilai akhir pada tabel normalisasi.

5. Nilai akhir pada tabel normalisasi merupakan hasil akhir dari penilaian metode Simple Additive Weighting (SAW)

6. Seluruh data perhitungan pada sistem adalah untuk mencari nilai tertinggi dari seluruh data yang diperoleh, sehingga rumus yang digunakan adalah Max (Benefit) sedangkan jika nilai yang ingin diperoleh adalah nilai terendah maka menggunakan rumus Min (Cost)

7. Dosen 1 (Basri, S.Kom.,MT), Dosen 2 (Akhmad Qashlim, S.Kom.,M.Kom), Dosen 3 (Syarli Jalal, S.Kom., M.Kom), Dosen 4 (Rosmawati Tamin,
S.Kom., M.Kom), dan Dosen 5 (Herlina Ahmad, S.Pd., M.Pd).

8. Hasil dari seluruh proses penilaian menunjukkan bahwa Dosen 2 (Akhmad Qashlim, S.Kom., M.Kom) memperoleh nilai akhir 38,63248719 dan keluar sebagai pemenang predikat Rangking 1 .

\section{SIMPULAN}

Berdasarkan hasil penelitian yang penulis lakukan mengenai Sistem Pendukung Keputusan Pemilihan Dosen Terbaik menggunakan Metode Simple Additive weighting (SAW) berdasarkan penilaian kriteria setiap dosen, penulis dapat menarik kesimpulan sebagai berikut:

1. Penentuan kriteria dan jumlah skor bobot kriteria adalah tahapan awal dalam penerapan metode simple additive weighting (SAW).

2. Metode Simple Additive Weighting (SAW) yang diterapkan dalam Sistem Pendukung Keputusan mampu memberikan perhitungan, perengkingan, dan solusi Pemilihan Dosen Terbaik untuk di rekomendasikan kepada pihak pimpinan.

3. Sistem yang dibangun dapat menjadi bahan pertimbangan oleh pihak Pimpinan Universitas Al Asyariah Mandar dalam proses pengambilan keputusan untuk menentukan penyandang predikat dosen terbaik.

\section{DAFTAR PUSTAKA}

Amiruddin, D., Nuryani, E., \& Faturrohmah, H. (2018). Rancangan Aplikasi Sistem Pendukung Keputusan ( SPK ) Pengangkatan Karyawan Menggunakan Metode Simple Additive Weighting ( SAW ) Pada PT . Ultra Prima Plast - Flexible Packaging. Jurnal Sistem Informasi Dan Informatika, 1(1), 1-18.

Marpaung, N., Handayani, M., \& Yesputra, R. (2018). Sistem pendukung keputusan pemilihan dosen terbaik dengan metode weighted product (wp) pada stmik royal. 9986(September).

Mufizar, T. (2016). Sistem Pendukung Keputusan Pemilihan Dosen Berprestasi Di STMIK Tasikmalaya Menggunakan Metode Simple Additive Weighting (SAW). CSRID (Computer Science Research and Its Development Journal), 7(3), 155. https://doi.org/10.22303/csrid.7.3.2015.155-166

Qashlim, A. (2015). Penerapan Metode Analytic Hierarchy Process (AHP) Untuk Sistem Pedukung Keputusan. 1, 8-14.

Rini, P. P., Dedi, \& Riyanti, N. (2015). Sistem Pendukung Keputusan Pemilihan Dosen Terbaik Berbasis Web Dengan Metode SAW (Simple Additive Weighting) (Studi Kasus: STMIK Global Tangerang). Sisfotek Global, 5(2), 9.

Sofhian, Sujaini, H., \& Sasty Pratiwi, H. (2016). Sistem Pendukung Keputusan Pemilihan Dosen Terbaik Menggunakan Metode Promethee ( Studi Kasus : 
Teknik Informatika Universitas Tanjungpura ). Register: Jurnal Ilmiah Teknologi Sistem Informasi, $\quad 5(1), \quad 1-6$. https://doi.org/10.14710/jtsiskom.5.4.2017.159-165

Sundari, S., Wanto, A., Saifullah, \& Gunawan, I. (2017). Sistem Pendukung Keputusan Dengan Menggunakan Metode Electre Dalam Merekomendasikan Dosen Berprestasi Bidang Ilmu Komputer (Study Kasus di AMIK \& STIKOM Tunas Bangsa). Seminar Nasional Multi Disiplin $\operatorname{Ilmu}, \mathrm{x}, 1-6$. 